\title{
Asymmetric Rhodium-Catalyzed [4+3] Cycloaddition
}

Metal-Catalyzed Asymmetric Synthesis and Stereoselective

Reactions

\section{Key words}

rhodium

tropanes

[4+3] cycloaddition<smiles>[R]c1cc2c(n1P)PCCC2</smiles><smiles>C=C(O[Ga])C(=N)C(=O)OC</smiles>

$\mathrm{R}^{1}=\mathrm{Boc}, \mathrm{Ph}, 4-\mathrm{MeC}_{6} \mathrm{H}_{4}$ $\mathrm{R}^{2}=\mathrm{H}, \mathrm{Me}$ $\mathrm{R}^{3}=\mathrm{Me}, \mathrm{CO}_{2} \mathrm{Me}, \mathrm{H}$; otherwise $\mathrm{R}_{3}-\mathrm{R}_{4}=-\mathrm{CH}_{2}\left(\mathrm{CH}_{2}\right)_{2} \mathrm{CH}_{2}-$

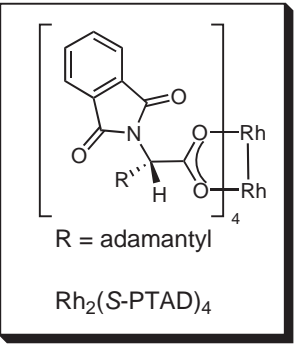
1) TBAF
2) $\mathrm{NaN}\left(\mathrm{SiMe}_{3}\right)_{2}$ $\mathrm{PhNTf}_{2}$
3) $\mathrm{PdCl}_{2}, \mathrm{PPh}_{3}$ $(n-\mathrm{Bu})_{3} \mathrm{~N}, \mathrm{HCO}_{2} \mathrm{H}$

$47 \%$ over 3 steps

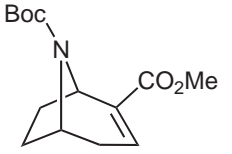

intermediate to biologically active tropanes

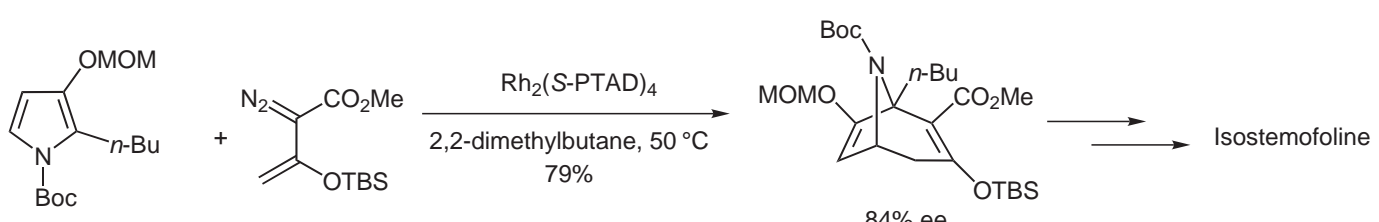

$84 \%$ ee

Significance: A novel methodology for the asymmetric synthesis of tropanes (a popular natural product scaffold) is described using a rhodiumcatalyzed [4+3] cycloaddition between pyrroles and a vinyldiazoacetate. The reaction tolerates a wide range of substituted pyrroles with good yields and excellent enantioselectivities. The products can be an intermediate or a precursor to an intermediate in several previously reported syntheses of biologically active tropanes.
Comment: The reaction proceeds by a tandem cyclopropanation-Cope rearrangement. The best catalyst for this reaction is $\mathrm{Rh}_{2}(\mathrm{~S}-\mathrm{PTAD})_{4}$, which limits the formation of some commonly observed side products. The reaction temperature is critical to achieve high conversions. 